\title{
On "asking for a kind of revolution" in clinical psychoanalysis: Winnicott's concept of regression, care-cure, working within the realm of needs and creating new experiences
}

\author{
Sobre "pedir por um tipo de revolução" na Clínica psicanalítica: \\ o conceito winnicottiano de refressão, cuidado-cura, trabalho no reino das \\ necessidades e criação de novas experiências
}

Ofra Eshel ${ }^{1}$ "I am asking for a kind of revolution in our work. Let us re-examine
what we do" (Winnicott, "DWW's notes for the Vienna Congress
never given" [because of his untimely death], 1971, p.1; cited in
Abram, 2013, pp. 1, 312)

\begin{abstract}
Resumo: neste artigo, abordo o rompimento radical das ideias teórico-clínicas de Winnicott a partir do trabalho psicanalítico tradicional, introduzindo uma mudança revolucionária na psicanálise clínica - uma transição de "extensão" para "revolução científica" e "mudança de paradigma" (para a usar a terminologia de Thomas Kuhn em "A estrutura das revoluções científicas", 1962). Para mim, essas ideias revolucionárias de Winnicott são muito importantes, tanto prática quanto teoricamente, pois fornecem uma matriz formative e um modo de trabalho e transformação que a prática psicanalítica não oferece.
\end{abstract}

Palavras-chave: Visão clínica revolucionária de Winnicott, Mudança de paradigma de Kuhn, regressão clínica, cuidado-cura, Treinamento Internacional em Psicanálise Winnicottiana em Beijing

Abstract: in this article, I will address the radical departure of Winnicott's theoretical-clinical ideas from traditional psychoanalytic work, introducing a revolutionary change in clinical psychoanalysis - a transition from "extension" to "scientific revolution" and "paradigm change or paradigm shift" (to use Thomas Kuhn's terminology of the "Structure of scientific revolution", 1962). For me, these revolutionary ideas of Winnicott are profoundly important,

\footnotetext{
${ }^{1}$ PsyD. is a training and supervising analyst and faculty member of the Israel Psychoanalytic Society, and member of the International Psychoanalytical Association (IPA). Vice-president of the International Winnicott Association (IWA). Founder and head of the post-graduate track "Independent Psychoanalysis: Radical Breakthroughs" at the advanced studies of the Program of Psychotherapy, Sackler Faculty of Medicine, Tel-Aviv University. She received the Leonard J. Comess Fund grant at the New Center for Psychoanalysis (NCP, Los Angeles, 2011), the David Hammond grant at the Massachusetts Institute for Psychoanalysis (MIP, Boston, 2016), was a visiting scholar at the Psychoanalytic Institute of North California (PINC, San Francisco, 2013), and visiting supervisor at the advanced International training program in Winnicott's psychoanalysis (Beijing, China, 2018). She is the book review editor of Sihot-Dialogue, Israel Journal of Psychotherapy; co-editor of the book Was It or Was It Not? When Shadows of Sexual Abuse Emerge in Psychoanalytic Treatment (2017, in Hebrew), and author of The Emergence of Analytic Oneness: Into the Heart of Psychoanalysis (Routledge, 2019). She awarded the 2013 Frances Tustin International Memorial Prize, and the 2017 Symonds Prize, and was featured in 2012 in Globes (Israel's financial newspaper and magazine) as sixteenth of the fifty most influential women in Israel. She is in private practice in Tel Aviv, Israel.
} 
theoretically and practically, as they provide a formative matrix and a mode of work and transformation that conventional psychoanalytic work does not offer (Eshel, 2013a, 2016, 2017a, 2019a, 2019b).

Keywords: Winnicott's revolutionary clinical vision, Kuhnian "paradigm change", clinical regression, care-cure, International Training Program in Winnicott's Psychoanalysis in Beijing

I have chosen to write here on this subject because Prof. Loparic's ideas on Winnicott's revolutionary vision have greatly supported and enriched my thinking. When I began writing on the paradigm shift of Winnicott's clinical thinking in 2006 (Eshel, 2009), I felt rather alone in this way of thinking, until a colleague came across and introduced me to Prof. Loparic's online article "Winnicott's Paradigm Outlined" (2002). And although Loparic's (2002, 2010) focus was on Winnicott's theoretical thinking with regard to mother-baby, two-body psychoanalysis that constitutes a Kuhnian "paradigm change" in Freud's Oedipal, triangular psychoanalysis, this was a true and powerful moment of meeting of minds. It launched our growing trans-continental communication on Winnicott's revolutionary vision over the past decade, ranging from aspects of Winnicott's paradigm change to the significance of Winnicott's "care-cure" ideas, at the international Winnicott training in Beijing in 2018. I have experienced in his thinking, writings and talks a daring spirit of exploration that has the potential to engender new possibilities from those we conventionally embrace.

\section{Winnicott's revolutionary clinical vision}

"From his early days as a psychoanalyst, Winnicott's quest is to address the stage of human development that precedes object relations", writes Abram (2008, p. 1189). I would suggest that from the outset, and over the years, Winnicott's way of exploring, experiencing, and practicing psychoanalysis consistently offered a revolutionary change in it, which is based on "essentially natural processes" $(1989$, p. 156). His core ideas of self-development and human subjectivity evolved out of very early infantile psychic processes and environmental motherinfant relatedness that precede object relationships, and these are powerfully applied to the treatment process and situation. His fundamental model of psychoanalytic treatment is the mother-infant, mother-child relationship. In addition, his theoretical and clinical thinking emphasizes core aspects of feeling alive or feeling real that were not considered by traditional psychoanalysis, and thus shifts from a language of instincts and wishes to a language of needs and environment. 
The revolutionary change of Winnicott's clinical thinking is profoundly linked to his theory of regression. This essentially means moving experientially beyond the space-time confines of traditional clinical psychoanalysis to work with primal processes in the treatment situation and setting, with the ensuing treatment priorities of holding, analytic reliability, and attentiveness to the patient's need states and dependence. Winnicott's clinical model of regression and its healing quality are based on providing in treatment "a new and reliable environmental adaptation which can be used by the patient in correction of the original adaptive failure [of the early maternal environment]" (1954a, p. 293) - thus enlarging the scope of psychoanalytic practice. "There was no class of illness that he considered impossible to analyze, as Freud regarded narcissistic neuroses and psychoses" (Little 1985, p. 39).

In a previous paper (Eshel, 2013a), I related to Winnicott's unique clinical thinking as constituting a paradigm shift, drawing primarily on his revision of the foundations of clinical psychoanalysis, and I entitled it "Reading Winnicott into Nano-Psychoanalysis". The title refers to concepts and terminology borrowed from nanoscience and nanotechnology, and in particular to physicist Richard Feynman's (1959) visionary presentation hailing nanotechnology and its radical potential: "There's plenty of room at the bottom - An invitation to enter a new field in physics". I paraphrased this title and applied it to Winnicott and to psychoanalysis as an invitation to enter and develop a new field of psychoanalysis. Indeed, Winnicott's psychoanalytic thinking, and particularly his clinical-technical theory, with its emphasis on regression in the treatment of more disturbed patients, share the fundamental principle proposed by Feynman and nanotechnology - that of going back to the "bottom", to the elemental early states and processes and to early mothering techniques, thereby enabling the initiation of formative developmental processes.

In my view, this is a psychoanalytic revolution that has been in process since the beginning of Winnicott's writing, although he tried to view his theory of regression in the analytic situation as an extension of Freud's work to areas Freud had not addressed (Winnicott 1954a, 1964, 1969). He did write in his last years: "Freud seems to me to be struggling to use what he knows to be true, because of his analytic experience, to cover what he does not know" (Winnicott, 1969, p. 240). But only at the very end of his life did he venture "[...] asking for a kind of revolution in our work" (Abram, 2013, p. 1, 312).

Abram (2013, p. 313), too, writes about this:

Perhaps by now, so near to death, Winnicott was able to articulate something that he had been in the process of since 1945---a psychoanalytic revolution. Thomas Kuhn had only just published his book The Structure of Scientific Revolutions (1962), and 
although Winnicott never refers to this book, his use of this word at the beginning of these notes suggests that he intuited his formulations were moving psychoanalysis toward something new.

Over the years, Winnicott explored, described, and struggled, theoretically and clinically, with "any degree" of regression to dependence, especially in the treatment of severely disturbed patients and also in difficult treatment situations with neurotic patients (1949a, 1949b, 1954a, 1954b, 1955--1956, 1963, 1964, 1967, 1988a, 1988b; see also Little, 1985). He "[...] fully believe[d]" that regression must be allowed "absolutely full sway" (Winnicott 1954a, p. 279), even to the earliest stages of prenatal life and rebirth. For regression carries with it, within the analytic process, the hope and a new opportunity for reliving, experiencing, and correcting the original maternal failure and inadequate adaptation-to-need in the patient's infancy and childhood, and the early traumatic unthinkable breakdown that happened at the time of early environmental failure. According to Winnicott:

All this can be very clearly demonstrated in psychoanalytic work provided one is able to follow the patient right back in emotional development as far as he needs to go, by regression to dependence, in order to get behind the period at which impingements became multiple and unmanageable [1949a, p. 192-3, italics added].

Thus, by providing the needed environmental essentials of holding, adaptation-to-need, reliability and protection, which should have been provided earlier but were not available, the therapist/analyst creates in the patient's life a facilitating environment in which development can start anew.

\section{Regression in the present tense in the treatment experience}

In Winnicott's revolutionary clinical model of regression and its healing quality, "the self cannot make new progress unless and until the [frozen] environment failure situation is [unfrozen and] corrected" (1954a, p. 291) through the analytic setting and process. Unless and until the deeply traumatic origins of the unthinkable, not-yet-experienced breakdown - which is therefore "past and future", never and forever - are relived and experienced "for the first time in the present" with the analyst (1974, p. 105). It is not a linear return to the past. The regression to dependence and early psychic processes in treatment calls forth a radical possibility of actually influencing and altering the patient's "past and future" in the present, by

[...] allow[ing] the past to be the present. Whereas in the transference neurosis the past comes into the consulting-room, in this work it is more true to say that the present goes back into the past, and $i s$ the past. Thus the analyst finds himself confronted with the 
patient's primary process in the setting in which it had its original validity. [Winnicott 1955--1956, pp. 297-298, italics in original]

Furthermore, Winnicott posits:

Let me add that for Freud there are three people, one of them excluded from the analytic room. If there are only two people involved then there has been a regression of the patient in the analytic setting, and the setting represents the mother with her technique, and the patient is an infant. There is a further state of regression in which there is only one present, namely the patient, and this is true even if in another sense, from the observer's angle, there are two. [1954a, p. 286]

This enables moving beyond the space-time confines of traditional clinical psychoanalysis and techniques to encompass and influence primal stages and processes of development, so that the treatment process actualizes a new experiential possibility within a new psychic environment ${ }^{2}$. The regression creates what has not existed and could not exist before. Winnicott writes:

In a peculiar way we can actually alter the patient's past, so that a patient whose maternal environment was not good enough can change into a person who has had a good enough facilitating environment, and whose personal growth has therefore been able to take place, though late. [1988a, p. 102].

Through Winnicott's words that convey and describe this innovative clinical-technical thinking, there emerge his profound belief, hope, quest, and yearning for a psychoanalytic treatment that would enable a new opportunity for correcting past experiences and forward emotional development for all patients, especially severely disturbed patients. This is a "hope of getting at something here in the analysis which had never been before" (1986, p. 32). Hence the critical importance of the analyst/therapist who now carries "the hope of a new opportunity for an unfreezing of the frozen situation and a chance for the environment, that is to say, the present-day environment, to make adequate though belated adaption" (1954a, p. 283).

Winnicott particularly relates to the need for therapeutic regression in the psychoanalytic treatment of schizoid, false self, borderline, and psychotic disorders, which constitute the third, most regressed group in Winnicott's 1954a classification (from my clinical experience, I would add patients with severe sexual perversions to this list of the most regressed group [Eshel, 2005, 2013b, 2017b]). Of the psychotic patient, he writes:

\footnotetext{
${ }^{2}$ Actualize is intended here in its two meanings: "In the present and in the process of actualization, that is, trying to bring into existence what didn't happen" (Pontalis, 2003, p. 45).
} 
The regression represents the psychotic individual's hope that certain aspects of the environment which failed originally may be relived, with the environment this time succeeding instead of failing in its function of facilitating the inherited tendency in the individual to develop and to mature. [1959--1964, p. 128]

Winnicott was very much aware of the great difficulties met in the course of psychoanalytic work with long, deep, or "total" regressions to dependence, which around the same time bothered two of his contemporaries - Balint in London and Nacht in Paris. Balint (1968, with regard to the basic fault psychopathology) and Nacht (1963) and Nacht and Viderman (1960) also dealt with the place of therapeutic regression in the psychoanalytic situation, but with rather restrained and cautious clinical-theoretical conclusions (Eshel, 2013a). The last thirty years have given rise to several critical reflections on this way of working with more disturbed patients, and its utility and necessity have been questioned (Spurling, 2008; Tyson and Tyson, 1990) and criticized (Segal, 2006). But Winnicott's clinical thinking insists on the fundamental transformative importance of such regressions for the patient, the analyst, and clinical psychoanalysis.

In his last year, in a talk on 18 October, 1970, three months before his death, Winnicott uses the term "care-cure", and states: "Psychoanalysis is not just a matter of interpreting the repressed unconscious; it is rather the provision of a professional setting for trust, in which such work may take place" (1970, p. 114-5). It is "care-cure" rather than the "talking cure," and this is linked, in my association, to his emphasis on the "carrying through of a treatment" (in Winnicott's 1954a paper on regression, p. 278) rather than "working through."

\section{Clinical illustration}

For the clinical illustration, because of Prof. Loparic major investment in the International Training Program in Winnicott's Psychoanalysis in Beijing, China, I have chosen the case presented by the Chinese psychotherapist Hongjun Li when I was a visiting supervisor at the Advanced International Training Program in Winnicott's Psychoanalysis in Beijing, in November 2018. I was moved to see at first hand how deeply significant Winnicott's clinical thinking, and especially this "care-cure" way of working, are for psychotherapists in a culture where discipline, obedience, shame, punishment, emotional restraint and denial are deeply embedded principles. Hongjun Li responds to her rejected, lonely and needy patient with caring, concern, reliability and protection, despite the pressures of the demanding and stressful reallife situation.

I find this a simple and very touching example. 


\section{The case of $O$.}

\subsection{Basic information}

Her name is $\mathrm{O}$. She is 14 years old. She is a junior high school student in grade two. When she was five years old, her parents got divorced. Her mother is a real estate agent. Her father works on a railway train. She came to treatment once a week, each time for a 60minute session. Until now, we have had 29 sessions. The fee is 400 yuan per hour (about US\$55).

\subsection{Reason for treatment}

O. has difficulty in studying and is the weakest student in her class. She cannot remember things well. Her relationships with other people are difficult and tense, and she cannot adapt to the school environment. She is very much rejected, punished and humiliated. She is self-involved, very angry and hopes that all the people in the world will behave according to her will. Her mother is very worried that in the future she will not be able to take care of herself.

O. has made several earlier attempts at suicide or self-harm, and also during the therapy period she may threaten to harm herself when faced with difficult situations.

\subsection{First impression}

She is thin, with very short hair. She is dressed like a boy, and also behaves like a boy. She is always smiling without any reason. She avoids direct eye contact, and her body is also avoidant. She seems frightened and does not know what to do.

\subsection{Life history}

Her parents got married when they were twenty. The mother was not ready to have a child yet. But she got pregnant by accident after marriage. All the elders in the family hoped to have a boy, but the baby turned out to be a girl. Until two years ago, only one child per family was permitted in China, and the birth of a girl was often very problematic. Then all the family members behaved very badly towards the mother and did not care about her anymore. When O. was a child, her parents argued with each other a lot. The mother is very angry. She said that she is a child herself, so she didn't have any patience for taking care of another child. The mother is very dominating and likes to be in control. O. told me, in front of her mother, that 
she is very nervous when her mother is around and doesn't know what to do or how to behave, because anything she says or does can trigger her mother's anger. When she was five years old, her parents got divorced, and she stayed with her father and the grandparents. She was treated badly by the family members. When she was very young, they would ask her to do a lot of farm work, and they often beat her. She remembered many things, for example, once she was locked in a room full of cactus plants and her whole body was filled with the thorns. She screamed very loudly but the grandma would not let her out. After her parents divorced, the mother would come to see her occasionally, and would buy her some food and groceries. But the grandma never gave her those things. O. lived in the grandma's house for three years. When she was eight years old, the mother came and took the girl back to live with her. Now she lives with her mother and the maternal grandparents. She has not seen her father even once since she left him. The mother told her that the father likes to gamble, and that he would sell her to pay his debts if he found her.

\subsection{My impressions of the mother}

She is a very quick-tempered person. She likes to talk a lot, and she is good at talking. Sometimes she would not stop talking and I could not interrupt her. The mother is a difficult woman. After the divorce, she raised O. all by herself, and because the father did not give her any alimony, she had a lot of financial problems. She is very dominating towards O. and often "educates" and criticizes her. But the mother herself also looks like a junior high school student. So, when they stand together, they are like sisters rather than mother and daughter. The mother complains frequently about O., but she is also worried that the child will not be able to adapt to the society in the future and that is why she brought her to therapy. However, it is difficult to cooperate with her - I invite her to come to parenting training sessions, but she refused to come. Whenever O. has some problems, the mother does nothing but criticize her. And when she has a breakdown, the mother calls me immediately and tells me that she can't take care of the child and asks me to do the job. I feel that the mother may stop the treatment at any moment, also because of the financial problems.

\subsection{The treatment}

\subsubsection{1st session}


The first time we met, O. came out of the elevator and she seemed totally confused. She couldn't tell the direction. She was like a fruit fly who flies without any goal. She's always smiling, but her body seemed to avoid something. It is as if she's very afraid to be touched.

After she came into the therapy room, she sat down very nervously in the corner of the couch. She did not dare to look at me. She held something in her hand and rubbed that thing repeatedly. I said to her, "I saw you are holding something. Is that true?" She said, "Yes, I have to hold something in my hands. Otherwise I will feel very nervous". She would rub the thing at the same time as she talked to me. From time to time, she would laugh. And after a little while, she would start to cry. While crying, she would wipe her tears. She said she did not want her mother to know that she was crying. She was afraid her mother would feel worried.

When we spoke, her words seemed to have no logic. She would talk about this and that without a clear theme. She said that the teachers and students are not nice to her in school and they bully her. But when I asked her when and how, she would say that she couldn't remember. She told me she couldn't remember things that happened in her life, especially things that happened in her childhood. Also, she couldn't relate to things she learned at school. She said she was a very unlucky girl. For example, she would fall down a lot as she walked, so she often gets hurt. She said she has diabetes, so she cannot eat as freely as she would like. There would always be some physical problems, so she frequently ended up in hospital. She spoke in a very simple way, jumped from one thing to another and couldn't describe in detail anything that she mentioned. I feel she's very confused, chaotic. She's also not coordinated in her feelings and perceptions. She has lost the sense of time and space. Her history is also fragmented. She's always in an alert and threatened mental state. It's as if she wants to tell me: "this environment is too horrible. I am cut into pieces".

When this session came to an end, I told her that "today you said a lot of important things to me. And I have remembered them all. I understand your situation and your trouble. I'm willing to help you'. She asked for my Wechat number and asked me whether she could contact me if she had some problems. I told her that I was usually busy, so maybe I wouldn't be able to respond to her message immediately, but if I had time, I would reply to her. From the next day, she would send me messages every day. Every time she would ask me, "are you there?", and then she would say to me that she couldn't bear it anymore. She would say, "I am mad! I am dying! Tell my mother that she will get my dead body tomorrow". I asked her what had happened. Then she would start to tell me something. For example, the little turtle that she raises in her house wouldn't play with her, and this drove her mad. The second day, she would say that the turtle was lying belly-up and it frightened her. The third day she would say that 
while she was going downstairs, she fell down and broke her leg. She also said that the students bullied her, and the teacher wanted to kick her out of the school. She couldn't stay in the school anymore. Her mother was also very critical, which made her feel she couldn't stay at home either. I had to console her in order to calm her down.

\subsection{2. $5^{\text {th }}$ session}

As soon as she sat down, she started to cry about what she experienced last week. She said, "The boys in my class always make fun of me. It drives me crazy. In the past, I would beat them. But now I am trying to tolerate it. But they are getting worse and worse. So, I couldn't stay in the school anymore". I ask her, "What did they do to you?". She said, "I was walking there, not doing anything. They would just come to me and hit me. I didn't do anything to them. They also badmouth me behind my back". I asked her, "Did you hear what they said about you?", and O. said, “No, I didn't. It's just that as soon as I walked by them, they would stare and point. And sometimes they would intentionally come to me and hit me. It frightened me". I said, "So you feel they are being violent towards you on purpose", "Yes," she said sadly. I said, "Are you often worried about other people being violent towards you? For example, that suddenly they will touch you, or they would shout your name. Because I saw that when you come to me, your body is always avoiding something. It's like you are afraid to be touched. It seems like you're afraid of something”. She cried and said, “I don't know what happened. I am always frightened. Sometimes when I'm sleeping, my mother would suddenly shout at me. Then I would be frightened and suddenly sit up. And when my grandpa was drunk, he often touched me. I would be really angry. My mother not only didn't help me, but she also said it was my problem". I said, "It seems that you're really sensitive to body touch. Sometimes a normal touch would be also be experienced by you as a strong one". She said, "I'm really afraid to be touched on the one hand, but on the other hand, I really wish that somebody would hug me. And that I could have someone to cling to, someone who makes me feel really secure and relaxed". I said, "Yes, actually, it's not that you don't like to be touched. It's just that you always want to be touched gently and softly. You really wish that there was somebody who could be with you and who you could cling to, somebody who would hug you gently and talk to you softly to make you feel secure. You wish there was somebody who you could rely on". She nodded repeatedly. I continue to say, "Maybe when you were really small, your care-giver couldn't figure out how much strength she should use to take care of you. Sometimes her touches were too rough, too hard. And sometimes her voice was too loud, or she would disturb 
you when you were sleeping, which made you feel very afraid". She said, "Maybe yes. My mother was very dominating and never cared about my feelings”. I said, “But it doesn't matter. Because now I will try to understand your need and take care of your need, and be with you so that you would feel more secure and relaxed". At that moment, she stopped rubbing her clothes and smiled at me and said, "Oh, I have never experienced that".

When the session ended, she said, “Teacher Li, can I hug you?", I said, "Yes.” She came to me but stopped before she hugged me. She smiled and said, "It's a little embarrassing. It's so embarrassing. We'd better just shake hands". And then she shook my hand and left happily.

$* \quad *$

After more than ten sessions, O. heard that in the city there was a school which trained people to be teachers for children, and that this school accepted junior high school students who had not graduated yet. She begged her mother to let her go to this school. Firstly, because she felt she couldn't stay in her current school anymore. The pressures of studying and the difficult relationships made her feel that she couldn't bear the school any longer. Secondly, she really likes the idea of becoming a teacher for children. Her mother also told her in the past that a teacher's job is suitable for her, because it's easier. But her mother was worried that she was not mature enough to go to this new school. However, she threatened her mother that she would leave the house. So, in the end, the mother compromised and allowed her to go to this school.

\subsection{3. $2^{\text {th }}$ session (The most recent one)}

On Friday morning, I saw that she had sent me a text last night saying, "I am going mad. Can I change our session time from Sunday to today?". I didn't have time to see her on Friday, so I replied her that I didn't have any spare time. I sent her a message to say that, "Can you wait until Sunday? I will listen to you carefully". And she said okay. The next day, her mother sent me a text saying that the class teacher had told her that $O$. had taken private pictures of her roommate, and somebody had reported this to the teacher. The student whose picture was taken was very angry. O. went back home, and her mother was very critical of her, saying that she was problematic, and they had a very big argument. The mother told me that $\mathrm{O}$. had been crying for two days and had lost control of her emotions and didn't want to go to school. She also didn't want to come to therapy. The mother asked me to call her and talk about it. I replied that I had made an agreement with O. to talk about it on Sunday. So, I told the mother she could tell O. to come the next day and we would have our regular session. If she didn't want to come, then she should call me herself and we could talk. The next day, Sunday, she came on time. 
She sat there. Her eyes were swollen, and she seemed very tired. I said to her, "It seems that you have experienced a lot of things recently. I can feel that you are not in a good state. I want to know what happened. Can you tell me?". She said, "Hasn't my mother told you about it yet?", and I said, "Your mother only told me something, but I'm not so clear about what exactly happened. I want to listen to you". She said, "I was driven crazy in these two days. I think they drove me to death. I cried for two days. I couldn't even walk. I couldn't recognize anybody". I said, "Who drove you crazy and to death? What exactly happened?". She said, "I can't remember", and I replied, "When you sent me messages, you said you want to talk to me in detail when we meet. So, in the last two days I've been thinking about you a lot. I'm waiting for you to say something to me. Don't you remember that?”. She answered, “Anyway, it's not like that anymore. I don't want to talk about it anymore. It's okay". I said, "I see you saying that on the one hand, but on the other hand you're crying. I think you must have a lot of grievance in your heart. Something must have happened in school. And I think you didn't get enough help when you came back home. Is that right?". She said, "My mother and my grandpa are like two machine guns. They shoot me with their words all the time and criticize me and say that I made a lot of trouble for them and say that I'm not mature and say that they can't bear me". I said, "Oh, when a child is treated badly outside, she wants to get some help from her family. You don't want to tell me, maybe because you think of me as the third machine gun. You imagine that I will be the same as them, that I will criticize you or say to you that you are also making a lot of trouble for me". She nodded and said, "I don't want to make any trouble for you". I continue to say, "But I won't do that. I'm not like that. And I am not afraid of you making any trouble. I want to know what happened. That's because I want to help you". She said, “My mother doesn't talk to me at all. Every week when I return home, she complains that I spend a lot of money and make her worry a lot. She never cares about what I experience in school. She never listens to me before she takes out all her emotions on me". I said, "Now you're in a new school. There is a lot of pressure. And it's not easy to get along with the new teachers and new classmates. You need a lot of help and support. I would really like to help you to go through this period of time". After a little while, she said, "Can I tell you about what happened on that day?" I said "yes." And she started to describe what happened in that day. She said, "At that time, my roommates and I were playing. And there was one student, A., who used her underwear to cover her face. Everybody took her picture. Me too. After I took that picture, I sent it to another roommate B. who was also taking pictures. I felt B. was my good friend and we were pretty close. So, I didn't think too much. But it turned out that B. deleted all the pictures that she had taken and sent my picture to A., telling A. that I had secretly taken 
some pictures of her. And then A. took these pictures and showed them to the teachers and said that I had violated her privacy. And then the teacher called my mother". While she was talking, I focused on her emotions and helped her to figure out what exactly happened. Then I said to her, “Things are not as bad as you imagined. You didn't do that intentionally. And also, you didn't send the pictures to other people. You can tell the teacher about it". She said, "Yes. I think I have to take some responsibilities for this thing. And the next time I won't do that. But they shouldn't gang up together against me. Now I want to talk to the teacher about the thing. In the past, I would always just suffer or keep silent. But now I want to change the passive attitude to the active attitude. Now I want to figure things out. Can I call my teacher here? Otherwise I'm afraid I won't tell the things clearly". I said, “Of course, you can. And I believe you can say it clearly. Because just now you described the whole thing to me very clearly. So, I believe you can also say that clearly to the teacher". But at the time, she didn't manage to get through to the teacher. So, she sent her a voice message and described exactly what had happened, and she also sent the chat record between her and her roommate $\mathrm{B}$. to the teacher, and she told the teacher that she would apologize to that friend A. again. In the end she said "I will go back to school". I said to her, "Just now you said you want to change the passive attitude to the active attitude. I am moved by your words. And I remember that you have dreams. You want to go to the college and in the future, you want to be a good teacher. I remember all that".

The session ended and I went with her to the elevator. She said, "Now, although it's very difficult, I think after this period of time, everything will be fine". I said, "I will be with you through this whole period".

\section{Concluding thoughts}

"I won't let that happen," says Ogden (2001, p. 166) spontaneously to his patient at the height of the patient's state of overwhelming anxiety and feelings of impending disintegration when recalling his childhood neglect and his molestation by a neighbor. "I was aware that I was promising a lot," writes Ogden (2001, p. 166), and in a telling footnote adds: "I do not believe that I could spontaneously have said [that] to the patient, had I not spent many years reading and rereading Winnicott's papers on the psyche-soma and the role of regression in the analytic process" (p. 171). "I won't let that happen" - now the analyst/therapist's being there with the patient, won't let that happen. 
"Now I will try to understand your need and take care of you and be with you so that you would feel more secure and relaxed," says Hongjun Li to her patient in far-away China ${ }^{3}$. And through the simple, everyday matters, which are so difficult, lonely and painful for her patient, Hongjun $\mathrm{Li}$ is being there with her, listening to her distress, really caring. And so, they struggle, patient-with-therapist, to create true hope of new opportunity; the hope that

In a peculiar way we can actually alter the patient's past, so that a patient whose maternal environment was not good enough can change into a person who has had a good enough facilitating environment, and whose personal growth has therefore been able to take place, though late (Winnicott, 1988a, p. 102).

\section{References}

Abram, J. (2008). Donald Woods Winnicott (1896-1971): A brief introduction. Int. J. Psychoanal. 89:1189-1217.

Abram, J. (2013). Introduction; also, DWW's notes for the Vienna Congress 1971: A consideration of Winnicott's theory of aggression and an interpretation of the clinical implication (2012). In: Abram J, editor. Donald Winnicott Today, pp. 1-25; 302-330. London and New York: Routledge, 2013.

Balint, M. (1968). The Basic Fault: Therapeutic aspects of regression. London: Tavistock/Routledge.

Eshel, O. (2005). Pentheus rather than Oedipus: on perversion, survival and analytic "presencing." Int. J. Psychoanal., 86:1071-1097.

Eshel, O. (2009). Introduction to Winnicott's two papers on regression in 1954. In: True Self, False Self: Winnicott Essays, 1935-1963 (translated to Hebrew), pp. 110-119. Tel-Aviv: Am Oved.

Eshel, O. (2013a). Reading Winnicott into Nano-Psychoanalysis: "There' s Plenty of Room at the Bottom". Psychoanal. Inquiry, 33:36-49.

Eshel, O. (2013b). Patient-analyst "withness": On analytic "presencing", passion, and compassion in states of breakdown, despair, and deadness. Psychoanal. Quarterly, 82: 925963.

Eshel, O. (2016). The "Voice" of Breakdown: On Facing the Unbearable Traumatic Experience in Psychoanalytic Work. Contemp. Psychoanal., 52(1):76-110.

Eshel, O. (2017a). From Extension to Revolutionary Change in Clinical Psychoanalysis: The Radical Influence of Bion and Winnicott. Psychoanal Q., 86(4):753-794.

\footnotetext{
${ }^{3}$ Over the last years, Hongjun Li read Winnicott's papers on the role of regression in the analytic process and Winnicott's paper on "care-cure" (1970).
} 
Eshel, O. (2017b). Beyond Sexuality, Beyond Perversion: The Annihilated Last Scream. Studies in Gender and Sexuality, 18(3):154-166.

Eshel, O. (2019a). The Vanished Last Scream: Winnicott And Bion. Psychoanal Q., 88(1):111-140.

Eshel, O. (2019b). The Emergence of Analytic Oneness: Into the Heart of Psychoanalysis. London and New York: Routledge.

Kuhn, T.S. (1962). The Structure of Scientific Revolutions. Chicago \& London: The University of Chicago Press.

Little, M. (1985). Winnicott working in areas where psychoanalytic anxieties predominate: a personal record. Free Association, 3: 9-42.

Loparic, Z. (2002). Winnicott's Paradigm Outlined. Available from:

http://www.centrowinnicott.com.br/.

Loparic, Z. (2010). From Freud to Winnicott: aspects of a paradigm change. In: Abram J, editor. Donald Winnicott Today, pp.113-156. London and New York: Routledge, 2013.

Nacht, S. (1963). The non-verbal relationship in psycho-Analysis treatment. Int. J.

Psychoanal., 44:333-339.

Nacht, S.; Viderman, S. (1960). The pre-object universe in the transference Situation. Int. J. Psychoanal., 41:385-388.

Ogden, T.H. (2001). Re-minding the body. In Conversations at the Frontiers of Dreaming, pp. 153-174. London: Karnac.

Pontalis, J.B. (2003). Windows. A. Quinney, translator. Lincoln, NE: University of Nebrasks Press.

Segal, H. (2006). Reflections on truth, tradition, and the psychoanalytic tradition of truth. American Imago, 63:283-292.

Spurling, L.S. (2008). Is There Still a Place for the Concept of 'Therapeutic Regression' in Psychoanalysis?. Int. J. Psychoanal., 89:523-540.

Tyson, P.; Tyson, R. L. (1963). Psychoanalytic Theories of Development: An Integration. New Haven, CT: Yale University Press.

Winnicott, D.W. (1949a). Birth memories, birth trauma and anxiety. In: Through Paediatrics to Psycho-Analysis, pp.174 - 193. London: Karnac Books, 1992.

Winnicott, D.W. (1949b). Mind and Its relation to the psyche-soma. In: Through Paediatrics to Psycho-Analysis, pp.243-254. London: Karnac Books, 1992. 
Winnicott, D.W. (1954a). Metapsychological and clinical aspects of regression within the psycho-analytical set-up. In: Through Paediatrics to Psycho-Analysis, pp.278-294. London: Karnac Books, 1992.

Winnicott, D.W. (1954b). Withdrawal and regression In: Through Paediatrics to PsychoAnalysis, pp.255-261. London: Karnac Books, 1992.

Winnicott, D.W. (1955-6). Clinical varieties of transference. In: Through Paediatrics to Psycho-Analysis, pp.259-299. London: Karnac Books, 1992.

Winnicott, D.W. (1959-1964). Classification: Is there a psycho-analytic contribution to psychiatric classification? In: The Maturational Processes and the Facilitating Environment, pp.124-139. London: Hogarth Press, 1965.

Winnicott, D.W. (1963). Dependence in infant-care, in child-care, and in the psycho-analytic Setting., In: The Maturational Processes and the Facilitating Environment, pp. 249-259. London: Hogarth Press, 1979.

Winnicott, D.W. (1964). The importance of the setting in meeting regression in psychoanalysis. In: Winnicott C. Shepherd R. Davis M., editors. Psycho-Analytic Explorations, pp. 96-102. London: Karnac Books, 1989.

Winnicott, D.W. (1967). The concept of clinical regression compared with that of defence organization. In: Winnicott C. Shepherd R. Davis M., editors. Psycho-Analytic Explorations, pp. 193-199. London: Karnac Books, 1989.

Winnicott, D.W. (1969). VII. The use of an object in the context of Moses and Monotheism. In: Winnicott C. Shepherd R. Davis M., editors. Psycho-Analytic Explorations, pp. 240-246. London: Karnac Books, 1989.

Winnicott, D.W. (1974). Fear of Breakdown. Int. Rev. Psychoanal., 1:103-107.

Winnicott, D.W. (1970). Cure. In: Winnicott C. Shepherd R. Davis M., editors. Home Is Where We Start From, pp. 112-120. Penguin Books, 1986.

Winnicott, D.W. (1986). Holding and Interpretation: Fragment of An Analysis. London: Karnac Books and the Institute of Psycho-Analysis.

Winnicott, D.W. (1988a). Babies and their Mothers. London: Free Association Press, 1986.

Winnicott, D.W. (1988b). Human Nature. Bollas C. Davis M. Shepherd R. editors. London: Free Association Press, 1986.

Winnicott, D.W. (1989). The Family and Individual Development. London/New York: Routledge. 